\title{
Synergistic response of auxin and ethylene on physiology of Jatropha curcas L.
}

\author{
Gargi Joshi', Arvind Shukla² and Alok Shukla ${ }^{1 *}$
}

\author{
${ }^{1}$ Department of Plant Physiology, College of Basic Sciences and Humanities, G.B. Pant University of Agriculture and \\ Technology, Pantnagar 263 145, India. \\ 2 Department of Genetics and Plant Breeding, College of Agriculture, G.B. Pant University of Agriculture and \\ Technology, Pantnagar 263 145, India.
}
* Correspondence: Department of Plant Physiology, College of Basic Sciences and Humanities, G.B. Pant University of Agriculture and Technology, Pantnagar 263 145, India. email: aloks_@yahoo.com, gargeejoshee@yahoo.com Received: 24 December 2010; Accepted: 24 February 2011.

\begin{abstract}
Jatropha curcas $\mathrm{L}$. is a versatile crop since all its plant material is brought to use either as energy source, industrial or medicinal purpose. Several studies are ongoing in different parts of the world to optimize, enhance and exploit the growth, fruiting cycle and different developmental stages of the plant so that the economic yield of the plants can be utilized to the fullest limits. Foliar application of plant growth regulators such as ethrel (an ethylene releasing compound), indole acetic acid (IAA) and naphthalene acetic acid (NAA) at 50, 100 and 150 ppm, was found to influence different morpho-physiological characters in Jatropha curcas $L$, such as plant height, collar diameter, tree spread, flower initiation, number of inflorescence per plant, number of male and female flowers per inflorescence, and the ratio of male: female flowers per inflorescence. Moreover, the leaves chlorophyll content, Fv/Fm value, nitrate reductase activity and proline content were also affected by synergistic response of auxin and ethylene. As higher the plant growth regulators concentration higher was the synergic effect on the Jatropha curcas $L$ physiology.
\end{abstract}

Key words: Jatropha curcas, auxin, ethrel, synergism, morpho-physiological.

\section{INTRODUCTION}

Due to the depleting petroleum reserves and detrimental environmental effects of exhaust gases from petroleum fuel, the exploitation of biofuels became extremely important. In September 2008 the Indian Government announced a biofuel policy with a proposal of $20 \%$ blending of biofuels with petrol and diesel by 2017 (Gahukar, 2009). Jatropha is a non-edible oil crop whose seeds contain viscous oil which can be used as a biofuel. It can be used for manufacture of other useful products such as soap, candles, medicines and cosmetic products. Jatropha also helps in carbon sequestration by increasing carbon stocks both above and below the ground.

Dehgan and Webster (1979) proposed that Jatropha curcas L., native of Central America, was the most primitive form of the Jatropha genus. Heller (1996) suggested that the genus name Jatropha derived from the Greek iatrós (doctor) and trophé (food) reflecting its medicinal usefulness. Katwal and Soni (2003) suggested that Jatropha was able to thrive in a number of climatic zones with rainfall of $250-1200 \mathrm{~mm}$. It was well adapted to arid and semi-arid conditions and had low fertility and moisture demand. It grew well on moderately saline, degraded and eroded soil. It may be raised from seeds or cuttings with an ideal plant density of 2500 stand/ha. The best period to plant stem cuttings is the rainy season. It reaches its maximum productivity in five years and can live up to 50 years. Gübitz et al. (1999) reported that Jatropha is cultivated in Central and South America, South East Asia, India and Africa. Twelve species are found in India with 
promising occurrence in the states of Andhra Pradesh, Gujarat, Rajasthan, Karnataka and Maharashtra. Jatropha curcas $\mathrm{L}$. is a deciduous shrub or small tree that grows to a height of about $5 \mathrm{~m}$. It has smooth bark, sturdy branches, and thick papery leaves. Branches contain latex. Plant is monoceious and flowers are unisexual, occasionally hermaphrodite flowers occur. According to Heller (1996), inflorescence is cyme type; formed terminally on branches, possessing main and co-florescences with paracladia. Normally five roots were formed from each seedlings, one central and four peripheral. Flowering in Jatropha occurred during wet season and two flowering peaks are obtained; one during summer and the other during autumn. This species bore fruits 3 to 4 years after being planted in the dry regions and reached the full fruit period in the fifth year.

According to Kochhar et al. (2005) the Central and State Governments drew ambitious programmes for Jatropha's large-scale cultivation due to its industrial and medicinal uses. Under semi-arid conditions the plant reclaimed marginal soils by exploring the soil with an adequate root system. This results in recycling nutrients from deeper soil layer. Chaudharry et al. (2007) reported that soil structure increased significantly after Jatropha curcas was grown for 18 months under semi-arid conditions in India; macroaggregate stability increased by $6-30 \%$ whereas soil bulk density was reduced by $20 \%$. There is need for a systematic study on the morphological traits, the relationships between genetic variability and economic yields of Jatropha in order to optimize its growth, fruiting cycle and different developmental stages which will ultimately enhance seed yield. Gadallah and Sayed (2001) suggested that exogenous application of hormones stimulated resistance against unfavourable environmental conditions and improved plant growth under stress. The effectiveness of growth regulators depends on their concentration and on the method of their application.

The aim of present study was to assess the synergistic effect of ethrel and auxins (IAA and NAA) in physiology of Jatropha curcas $L$. plants. It was found that all the growth regulators were significantly beneficial in enhancing growth and yield parameters of the plants. The higher concentration of the plant growth regulators the most prominent was the effect on the morpho-physiological characters of the Jatropha plants.

\section{MATERIALS AND METHODS}

In the present study four year old uniform plants of Jatropha curcas L. were selected and cultivated at Medicinal Plant Research and Development Centre, Haldi, G.B. Pant University of Agriculture and Technology, Pantnagar. The plant to plant spacing was $3 \mathrm{~m} \times 3 \mathrm{~m}$. The field was harrowed and cross-harrowed in dry conditions. The source of fertilizers was urea (applied in two splits at of $10 \mathrm{~g} / \mathrm{plant}$ ), diammonium phosphate at of $100 \mathrm{~g} / \mathrm{plant}$ and vermicompost at of $100 \mathrm{~g} /$ plant respectively. All the trees were maintained in uniform cultural treatments during the course of investigation.

The plant growth regulators were applied as foliar spray in the month of September during the pre-flowering stage. Ethrel, IAA and NAA were sprayed at of $50 \mathrm{ppm}, 100$ ppm and 150 ppm in water containing 0.05\% Tween- 20. The control set of plants were sprayed with distilled water containing $0.05 \%$ Tween -20 only to the whole plant to runoff especially focusing on the growing points. The study was conducted for a period of two consecutive years of 2008 and 2009.

The different morpho-physiological parameters such as growth parameters, flowering and yield parameters were recorded at the end of vegetative and reproductive period. The growth parameters recorded were tree height, collar diameter, tree spread, and tree volume. The different flowering parameters recorded at the time of reproductive stage were days to initiation of flowers after spray of plant growth regulators, the number of inflorescence per plant after spray with plant growth regulators, number of male flowers per inflorescence and female flowers per inflorescence, ratio of male and female flowers/ inflorescence as influenced by different growth regulators. The yield parameters recorded were number of fruit yield per plant and seed yield per plant. The biochemical parameters were measured at three growth stages- pre-flowering stage, flowering and maturity stage. Chlorophyll content was measured using DMSO according to Hiscox and Israeltam (1979). SPAD was measured using SPAD meter, PEA meter was used for measuring Fv/Fm ratio as photosynthetic efficiency, nitrate reductase activity was measured by the method of Hageman and Huckelsby (1971), crude protein content was measured by the Microkjeldahl method given by Jeckson (1973) and proline content was measured according to Bates et al. (1973). 


\section{Statistical analysis}

The data obtained from field trials during the course of the present investigation were analysed statistically by using the random block design (RBD) and the laboratory experiments were analysed by completely randomized designs (CRD) the standard mean error (SEm) and critical difference (CD) was evaluated at $5 \%$ level of significance. All the experiments were carried out taking three replicates for each treatment.

\section{RESULTS}

Spraying the plant growth regulators on Jatropha plants at pre- flowering stage had pronounced effects on the morphological characters of the species (Table1). Plant growth regulators caused an increase in the height of the plants. Addition of auxins, both IAA and NAA significantly increased the height of the plants whereas plants sprayed with Ethrel were smaller compared to control plants (Table 1). The height of the control plants for the year 2008 and 2009 was $2.025 \pm 0.060 \mathrm{~m}$ and $2.458 \pm 0.341 \mathrm{~m}$. For the year 2008 and 2009 NAA 150 ppm treated plants recorded a height of $2.240 \pm 0.144 \mathrm{~m}$ and $2.917 \pm 0.042 \mathrm{~m}$. The collar diameter of the plants was significantly affected by the plant growth regulators in both the years. Ethrel (100 and $150 \mathrm{ppm})$, IAA (50, $100 \mathrm{ppm}$ and $150 \mathrm{ppm}$ ) and NAA (50 and 100ppm) caused a significant increase in the collar diameter of the plants compared to control plants (Table 1). Ethrel $150 \mathrm{ppm}$ treated plants reached an annual diameter of $13.075 \pm 1.101 \mathrm{~cm}$ and $15.841 \pm 0.061 \mathrm{~cm}$ in 2008 and 2009 respectively. Spread of the tree in NS (North-South) and EW (East- West) direction and the tree volume was affected pronouncedly at the higher doses of plant growth regulators. Ethrel treatment of 100 and 150 ppm showed a significant decrease in the tree spread whereas auxin treatment (IAA and NAA) increased the tree spread compared to control (Table 1). Tree spread in control was $1.870 \pm 0.022 \mathrm{~m}$ in 2008 and $2.604 \pm 0.104$ in 2009. In Ethrel $150 \mathrm{ppm}$ treated plants it was recorded as $1.695 \pm 0.0462 \mathrm{~m}$ in 2008 and $2.157 \pm 0.036 \mathrm{~m}$ in 2009. In IAA $150 \mathrm{ppm}$ treated plants it was recorded as $2.048 \pm 0.030 \mathrm{~m}$ and $2.941 \pm 0.054 \mathrm{~m}$ in 2008 and 2009 . In NAA 150 ppm treated plants it was $2.090 \pm 0.046$ in the year 2008 and $2.951 \pm 0.061$ in 2009. Tree volume in Ethrel $150 \mathrm{ppm}$ treated plants was $2.762 \pm 0.238 \mathrm{~m}^{3}$ in 2008 and $4.895 \pm 0.275 \mathrm{~m}^{3}$ in 2009. IAA $150 \mathrm{ppm}$ treated plants recorded tree volume as $4.163 \pm 0.056 \mathrm{~m}^{3}$ in 2008 and $12.674 \pm 0.369 \mathrm{~m}^{3}$ in 2009 compared to control which recorded $3.705 \pm 0.168 \mathrm{~m}^{3}$ in 2008 and $9.053 \pm 2.093 \mathrm{~m}^{3}$ in 2009.

Table 1. Effect of plant growth regulators on growth pattern of Jatropha curcas $L$.

\begin{tabular}{|c|c|c|c|c|c|c|c|c|}
\hline \multirow{2}{*}{ Treatment } & \multicolumn{2}{|c|}{ Tree Height (m) } & \multicolumn{2}{|c|}{ Collar diameter (cm) } & \multicolumn{2}{|c|}{ Tree spread (m) } & \multicolumn{2}{|c|}{ Tree volume $\left(\mathrm{m}^{3}\right)$} \\
\hline & 2008 & 2009 & 2008 & 2009 & 2008 & 2009 & 2008 & 2009 \\
\hline Control & $2.03 \pm 0.06$ & $2.46 \pm 0.34$ & $9.70 \pm 0.21$ & $13.78 \pm 0.31$ & $1.87 \pm 0.02$ & $2.60 \pm 0.10$ & $3.71 \pm 0.17$ & $9.05 \pm 2.09$ \\
\hline Ethrel $_{50 \mathrm{ppm}}$ & $1.98 \pm 0.01$ & $2.30 \pm 0.03$ & $10.44 \pm 0.26$ & $14.67 \pm 0.27$ & $1.81 \pm 0.02$ & $2.50 \pm 0.11$ & $3.27 \pm 0.14$ & $7.61 \pm 0.76$ \\
\hline Ethrel $_{100 p p m}$ & $1.94 \pm 0.05$ & $2.15 \pm 0.03$ & $11.29 \pm 0.78$ & $15.83 \pm 1.49$ & $1.76 \pm 0.03$ & $2.31 \pm 0.11$ & $3.15 \pm 0.16$ & $6.06 \pm 0.65$ \\
\hline Ethrel $_{150 \mathrm{ppm}}$ & $1.85 \pm 0.06$ & $2.03 \pm 0.06$ & $13.08 \pm 1.10$ & $15.84 \pm 0.06$ & $1.69 \pm 0.05$ & $2.16 \pm 0.04$ & $2.76 \pm 0.24$ & $4.89 \pm 0.27$ \\
\hline $\mathrm{IAA}_{50 \mathrm{ppm}}$ & $2.16 \pm 0.09$ & $2.53 \pm 0.36$ & $12.20 \pm 0.52$ & $16.03 \pm 0.44$ & $1.91 \pm 0.03$ & $2.73 \pm 0.07$ & $4.06 \pm 0.39$ & $9.87 \pm 1.31$ \\
\hline$I_{A} A_{100 p p m}$ & $2.19 \pm 0.06$ & $2.76 \pm 0.24$ & $11.54 \pm 0.39$ & $15.98 \pm 0.43$ & $1.99 \pm 0.01$ & $2.83 \pm 0.04$ & $4.44 \pm 0.16$ & $11.57 \pm 1.07$ \\
\hline $\mathrm{IAA}_{150 \mathrm{ppm}}$ & $2.31 \pm 0.00$ & $2.80 \pm 0.07$ & $11.09 \pm 0.37$ & $15.87 \pm 0.69$ & $2.05 \pm 0.03$ & $2.94 \pm 0.05$ & $4.16 \pm 0.06$ & $12.67 \pm 0.37$ \\
\hline $\mathrm{NAA}_{50 \mathrm{ppm}}$ & $2.15 \pm 0.08$ & $2.69 \pm 0.21$ & $12.00 \pm 1.03$ & $16.83 \pm 0.64$ & $1.93 \pm 0.02$ & $2.71 \pm 0.04$ & $4.68 \pm 0.09$ & $10.37 \pm 0.92$ \\
\hline $\mathrm{NAA}_{100 \mathrm{ppm}}$ & $2.18 \pm 0.13$ & $2.79 \pm 0.19$ & $11.36 \pm 0.08$ & $15.77 \pm 0.89$ & $2.01 \pm 0.02$ & $2.82 \pm 0.03$ & $4.61 \pm 0.38$ & $11.62 \pm 0.59$ \\
\hline $\mathrm{NAA}_{150 \mathrm{ppm}}$ & $2.24 \pm 0.14$ & $2.92 \pm 0.04$ & $10.24 \pm 0.57$ & $14.24 \pm 0.71$ & $2.09 \pm 0.05$ & $2.95 \pm 0.06$ & $4.93 \pm 0.37$ & $13.30 \pm 0.57$ \\
\hline S.Em. & 0.0753 & 0.171 & 0.525 & 0.616 & 0.273 & 0.399 & 0.229 & 0.757 \\
\hline $\mathrm{CD}$ at $5 \%$ & 0.219 & 0.499 & 1.533 & 1.8 & 0.798 & 0.116 & 0.67 & 2.209 \\
\hline
\end{tabular}

Synergism of ethrel, IAA and NAA proved beneficial in decreasing vegetative phase and early initiation of the reproductive phase showed by early initiation of flowering in Jatropha curcas plants after spray of plant growth regulators. The data are presented in the Table 2a and Figure 1. Among the various concentrations of the ethrel sprays, $150 \mathrm{ppm}$ had the greatest effect in initiation of flowering within $23.000 \pm 0.763$ days after spray in 2008 and 
$25.000 \pm 1.000$ days in 2009 compared to control plants that flowered $39.166 \pm 0.600$ days after spray in 2008 and $38.000 \pm 0.500$ days in 2009. Plant growth regulators increased the number of inflorescence per plant and the number of both male and female flowers thus increasing the trend towards femaleness in comparison to control. Ratio of male to female flowers decreased significantly with plant growth regulators. Higher doses of growth regulators ethrel 150 ppm, IAA 150 ppm and NAA 150 ppm had a more pronounced effect on the number of female flowers of Jatropha curcas plants as represented in Table $2 \mathrm{a}$ and Figure 2 and 3 . The ratio of male to female flowers in ethrel $150 \mathrm{ppm}$ treated plants was $24.000 \pm 1.23$ in 2008 and $21.000 \pm 0.77$ in 2009.

Table 2a. Effect of plant growth regulators on flowering and yield pattern of J. curcas $L$.

\begin{tabular}{lcccccccc}
\hline & \multicolumn{2}{c}{ Flower Initiation (days) } & \multicolumn{2}{c}{$\begin{array}{c}\text { No. of female flowers/ } \\
\text { inflorescence }\end{array}$} & \multicolumn{2}{c}{$\begin{array}{c}\text { No. of male flowers/ } \\
\text { inflorescence }\end{array}$} & \multicolumn{2}{c}{$\begin{array}{c}\text { Ratio of male: female flowers/ } \\
\text { innflorescene }\end{array}$} \\
\cline { 2 - 8 } & $\mathbf{2 0 0 8}$ & $\mathbf{2 0 0 9}$ & $\mathbf{2 0 0 8}$ & $\mathbf{2 0 0 9}$ & $\mathbf{2 0 0 8}$ & $\mathbf{2 0 0 9}$ & $\mathbf{2 0 0 8}$ & $\mathbf{2 0 0 9}$ \\
\hline Control & $39.17 \pm 0.60$ & $38.00 \pm 0.50$ & $3.00 \pm 0.01$ & $3.67 \pm 0.17$ & $81.00 \pm 1.53$ & $98.00 \pm 1.15$ & $27.00 \pm 0.9$ & $26.73 \pm 1.3$ \\
threl $_{50 \mathrm{ppm}}$ & $29.33 \pm 0.88$ & $29.33 \pm 0.44$ & $3.33 \pm 0.17$ & $4.33 \pm 0.17$ & $86.67 \pm 1.67$ & $106.00 \pm 1.15$ & $26.00 \pm 1.0$ & $24.46 \pm 1.5$ \\
Ethrel $_{100 \mathrm{ppm}}$ & $26.83 \pm 0.88$ & $28.00 \pm 1.61$ & $3.67 \pm 0.17$ & $4.67 \pm 0.17$ & $91.33 \pm 0.33$ & $101.33 \pm 0.88$ & $24.19 \pm 0.6$ & $21.71 \pm 1.0$ \\
Ethrel $_{150 \mathrm{ppm}}$ & $23.00 \pm 0.76$ & $25.00 \pm 1.00$ & $4.00 \pm 0.00$ & $5.00 \pm 0.04$ & $96.00 \pm 1.15$ & $105.00 \pm 1.89$ & $24.00 \pm 1.2$ & $21.00 \pm 0.8$ \\
IAA $_{50 \mathrm{ppm}}$ & $28.33 \pm 1.48$ & $30.17 \pm 2.68$ & $3.50 \pm 0.29$ & $4.17 \pm 0.44$ & $91.00 \pm 0.58$ & $96.00 \pm 1.15$ & $26.00 \pm 0.8$ & $24.00 \pm 1.2$ \\
IAA $_{100 \mathrm{ppm}}$ & $25.33 \pm 2.19$ & $26.00 \pm 0.29$ & $3.67 \pm 0.33$ & $4.50 \pm 0.29$ & $91.33 \pm 0.33$ & $103.50 \pm 1.13$ & $24.91 \pm 1.0$ & $23.00 \pm 0.5$ \\
IAA $_{150 \mathrm{ppm}}$ & $24.00 \pm 1.50$ & $24.00 \pm 1.00$ & $4.00 \pm 0.29$ & $4.67 \pm 0.17$ & $98.00 \pm 0.58$ & $99.00 \pm 1.00$ & $24.50 \pm 1.0$ & $21.21 \pm 1.7$ \\
NAA $_{50 \mathrm{ppm}}$ & $28.83 \pm 1.17$ & $30.00 \pm 0.00$ & $3.50 \pm 0.29$ & $4.33 \pm 0.17$ & $92.00 \pm 0.00$ & $112.50 \pm 0.76$ & $26.29 \pm 0.9$ & $25.96 \pm 1.5$ \\
NAA $_{100 \mathrm{ppm}}$ & $27.67 \pm 0.60$ & $28.50 \pm 2.84$ & $3.67 \pm 0.44$ & $4.83 \pm 0.17$ & $95.00 \pm 0.58$ & $117.50 \pm 1.50$ & $25.91 \pm 1.2$ & $24.31 \pm 1.2$ \\
NAA $_{150 \mathrm{ppm}}$ & $25.67 \pm 1.45$ & $26.00 \pm 0.58$ & $3.83 \pm 0.17$ & $5.00 \pm 0.10$ & $96.00 \pm 0.58$ & $112.50 \pm 0.76$ & $25.04 \pm 0.9$ & $22.50 \pm 1.0$ \\
S.Em. & 1.004 & 1.381 & 0.148 & 0.21 & 1.709 & 2.432 & 0.433 \\
CD at 5\% & 2.93 & 4.031 & 0.434 & 0.613 & 4.989 & 7.1 & 0.565 \\
\hline
\end{tabular}

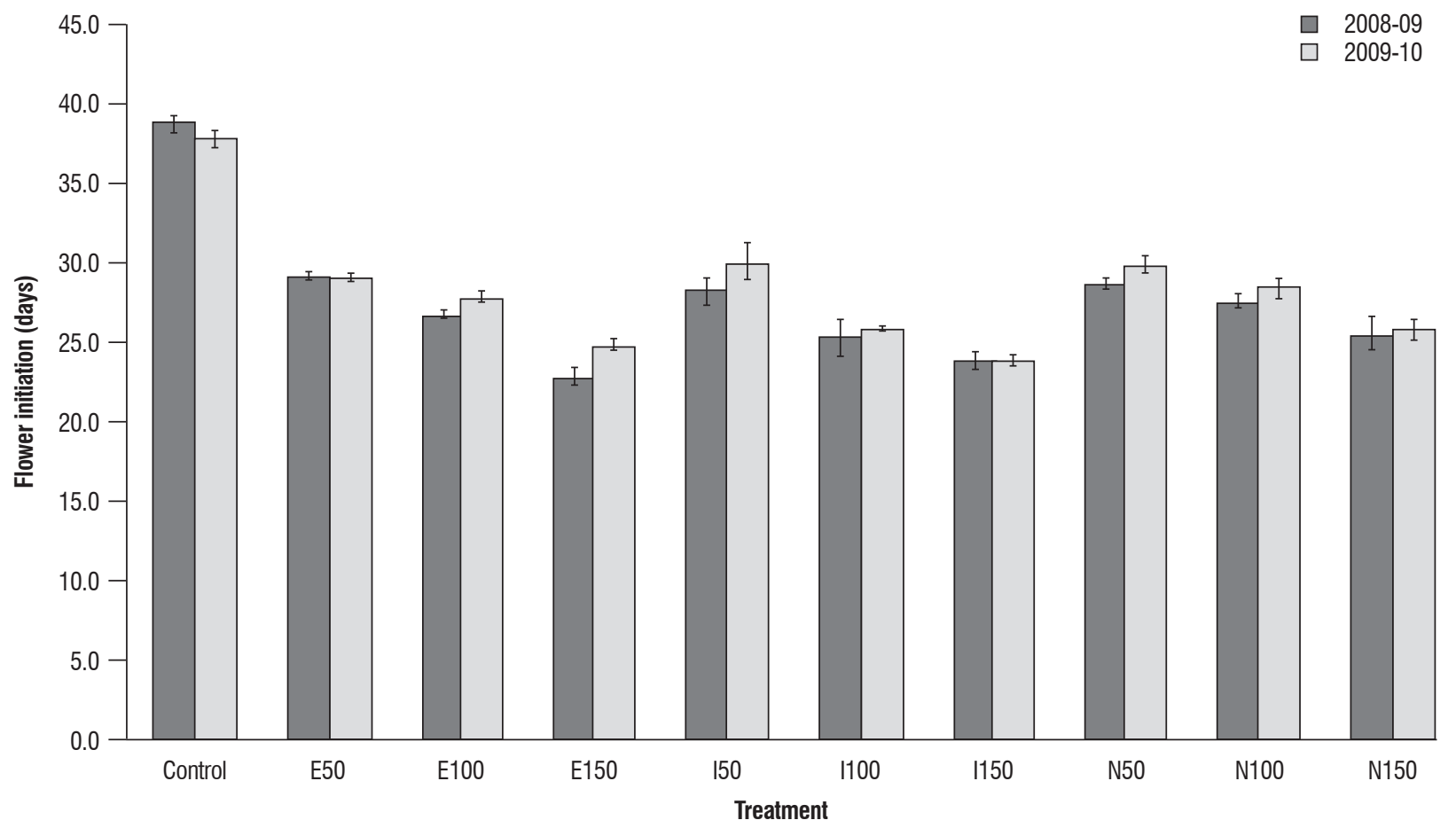

Figure 1. Flower initiation (days) of Jatropha curcas L. Pant J- Selection 2 in field condition treated with different plant growth regulators in the year 2008-09 and 2009-10. Error bars indicate SE from three replications. 
ETHYLENE ON PHYSIOLOGY OF Jatropha curcas L.

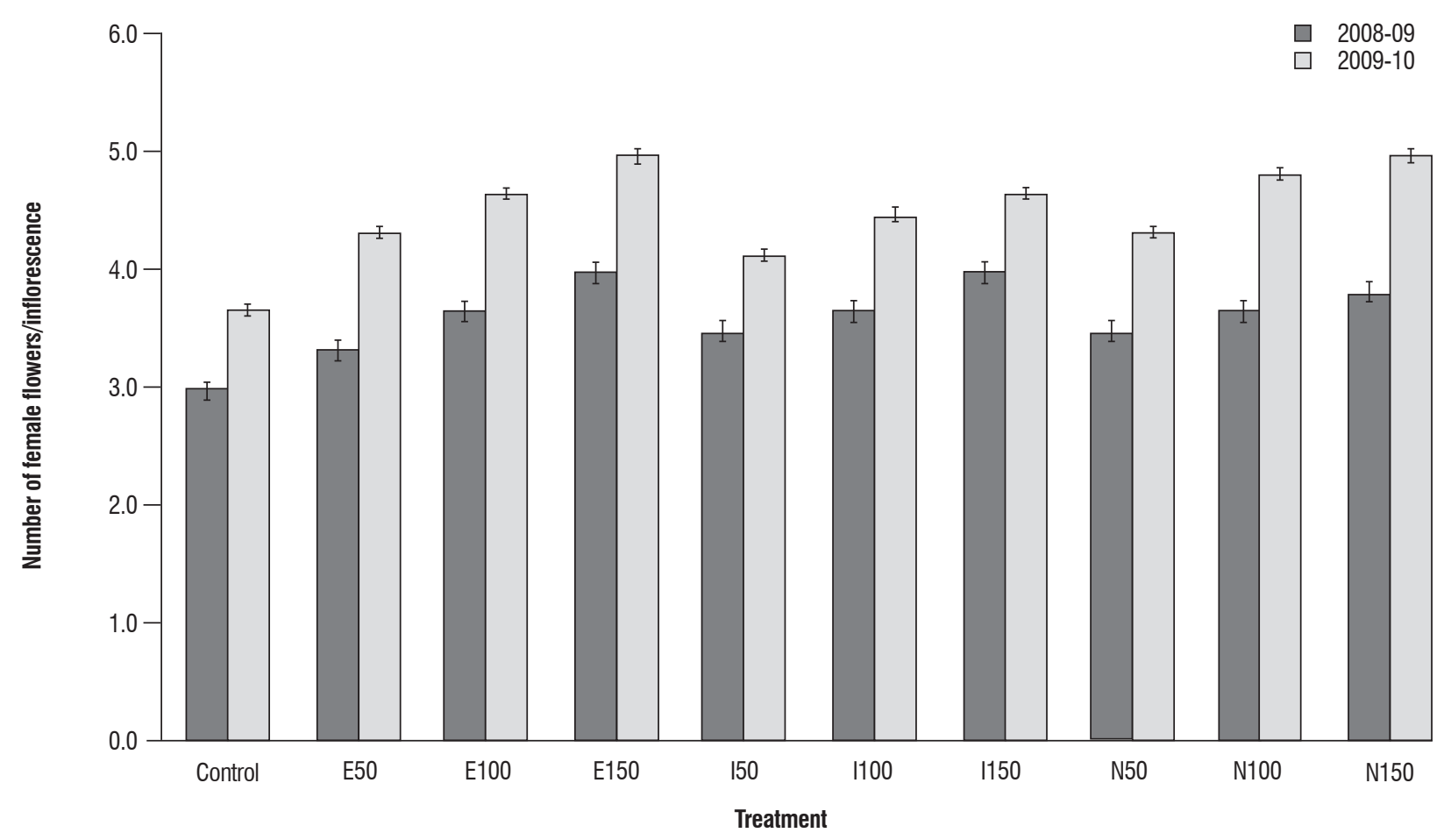

Figure 2. Number of female flowers/Inflorescence of Jatropha curcas L. Pant J-Selection 2 in field condition treated with different plant growth regulators in the year 2008-09 and 2009-10. Error bars indicate SE from three independent experiments.

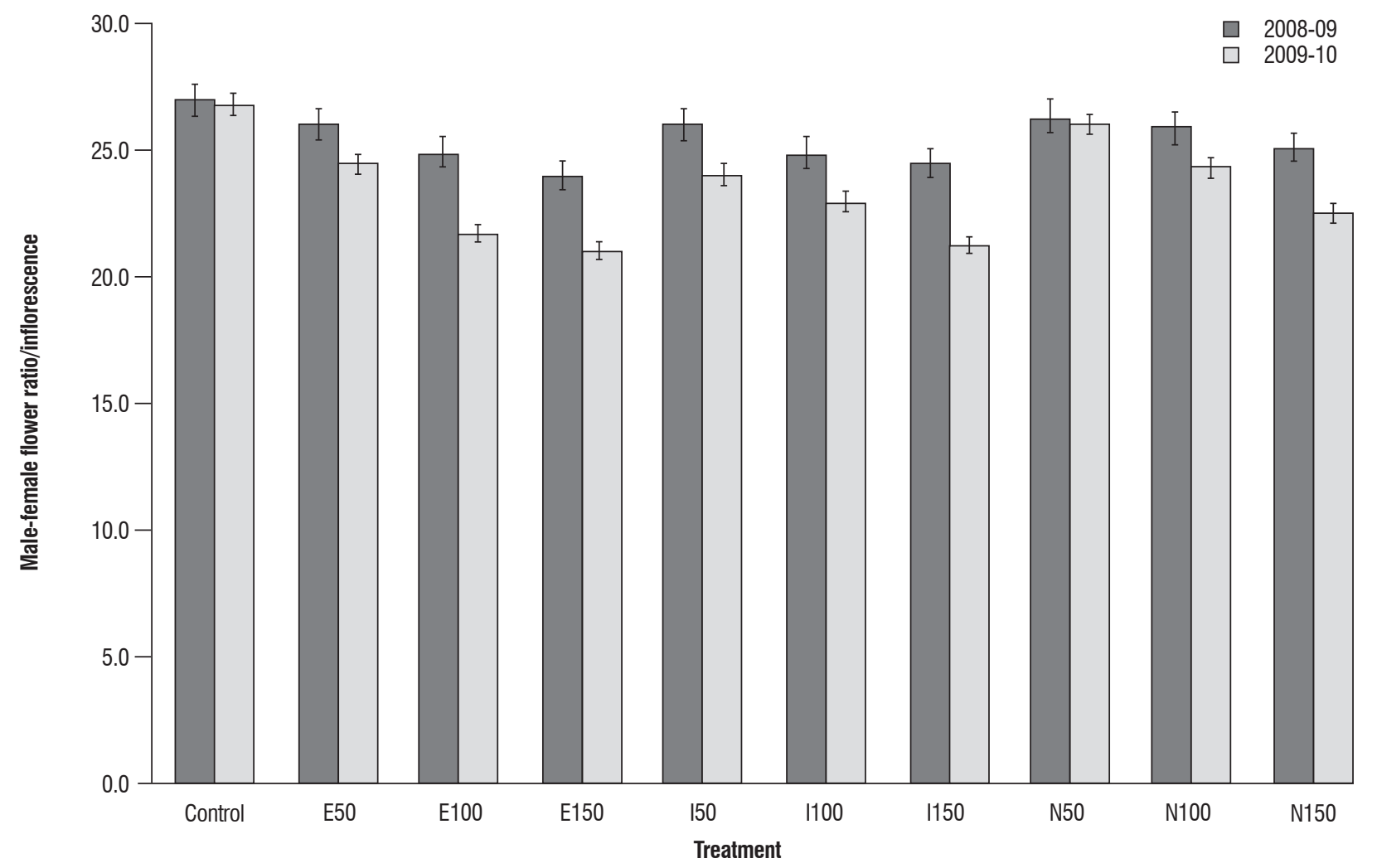

Figure 3. Male-female flowers ratio/ Inflorescence of Jatropha curcas L. Pant J- Selection 2 in field condition treated with different plant growth regulators in the year 2008-09 and 2009-10. Error bars indicate SE from three independent experiments. 
The results indicated that the plants treated with growth regulators had a significant increase in the yield compared to untreated plants in both the years of study (Table 2b, Figure 4 and 5). A considerable increase in fruit yield per plant and seed yield per plant was observed compared with control after the application of plant growth regulators. The ethrel spray at all concentrations increased the fruit and seed yield per plant. These parameters increased with the increase in the concentrations of the spray. Fruit yield per plant observed in trees sprayed with ethrel $150 \mathrm{ppm}$ in the year 2008 was $28.278 \pm 8.981 \mathrm{~g}$ and in 2009 was $31.776 \pm 14.272 \mathrm{~g}$. Whereas the seed yield per plant by the same treatment was $12.935 \pm 4.208$ $\mathrm{g}$ in 2008 and in 2009 was $14.583 \pm 5.720 \mathrm{~g}$.

Table $\mathbf{2 b}$. Effect of plant growth regulators on yield pattern of $J$. curcas $\mathrm{L}$.

\begin{tabular}{|c|c|c|c|c|}
\hline \multirow{2}{*}{ Treatment } & \multicolumn{2}{|c|}{ Fruit yield/ plant (g) } & \multicolumn{2}{|c|}{ Seed yield/ plant (g) } \\
\hline & 2008 & 2009 & 2008 & 2009 \\
\hline Control & $3.33 \pm 0.44$ & $6.28 \pm 2.49$ & $1.63 \pm 0.21$ & $3.04 \pm 1.28$ \\
\hline Ethrel $_{50 \mathrm{ppm}}$ & $5.36 \pm 0.51$ & $9.41 \pm 1.35$ & $2.65 \pm 0.24$ & $3.95 \pm 1.02$ \\
\hline Ethrel $_{100 \mathrm{ppm}}$ & $17.38 \pm 1.31$ & $23.59 \pm 3.88$ & $8.21 \pm 0.68$ & $11.22 \pm 1.48$ \\
\hline Ethrel $_{150 \mathrm{ppm}}$ & $28.28 \pm 8.98$ & $31.78 \pm 14.27$ & $12.94 \pm 4.21$ & $14.58 \pm 5.72$ \\
\hline IAA ${ }_{50 \mathrm{ppm}}$ & $14.95 \pm 1.95$ & $15.46 \pm 3.09$ & $7.20 \pm 1.19$ & $7.79 \pm 1.40$ \\
\hline$I_{1} A_{100 p p m}$ & $20.32 \pm 14.30$ & $21.00 \pm 3.96$ & $9.50 \pm 6.61$ & $9.69 \pm 1.58$ \\
\hline$I_{1} A_{150 p p m}$ & $27.35 \pm 7.73$ & $33.21 \pm 10.35$ & $12.78 \pm 3.66$ & $15.68 \pm 4.88$ \\
\hline$N A A_{50 p p m}$ & $15.69 \pm 1.30$ & $14.66 \pm 2.19$ & $7.45 \pm 0.82$ & $7.21 \pm 1.27$ \\
\hline $\mathrm{NAA}_{100 \mathrm{ppm}}$ & $17.19 \pm 1.22$ & $19.18 \pm 4.84$ & $7.97 \pm 0.29$ & $9.09 \pm 2.12$ \\
\hline $\mathrm{NAA}_{150 \mathrm{ppm}}$ & $25.96 \pm 5.13$ & $29.96 \pm 8.94$ & $9.67 \pm 0.78$ & $13.73 \pm 3.52$ \\
\hline S.Em. & 1.323 & 1.91 & 0.773 & 0.704 \\
\hline CD at $5 \%$ & 3.864 & 5.575 & 2.256 & 2.057 \\
\hline
\end{tabular}



Figure 4. Number of fruit yield/plant of Jatropha curcas L. Pant J-Selection 2 in field condition treated with different plant growth regulators in the year 2008-09 and 2009-10. Error bars indicate SE from three independent experiments. 




Figure 5. Seed yield/plant of Jatropha curcas L. Pant J- Selection 2 in field condition treated with different plant growth regulators in the year 2008-09 and 2009-10. Error bars indicate SE from three independent experiments.

The spray of plant growth regulators on Jatropha plants positively affected the different biochemical parameters (Table 3). Ethrel $150 \mathrm{ppm}$ and IAA and NAA $150 \mathrm{ppm}$ had the most significant effect on these parameters. Total chlorophyll content was found to be stimulated significantly by the spray of ethrel, IAA and NAA. Prominent increase was found during vegetative and reproductive stage. The effect was more prominent with the higher concentration of plant growth regulators (Table 3). Control plants had a chlorophyll content of $1.805 \pm 0.07$ $\mathrm{mg} / \mathrm{g}$ fresh weight and $1.811 \pm 0.10 \mathrm{mg} / \mathrm{g}$ fresh weight in the year 2008 and 2009 respectively. The amount of chlorophyll content in ethrel $150 \mathrm{ppm}$ treated plants was $1.824 \pm 0.05$ $\mathrm{mg} / \mathrm{g}$ fresh weight and $1.828 \pm 0.03 \mathrm{mg} / \mathrm{g}$ fresh weight for the year 2008 and 2009 respectively.

According to Munns and others (2006) SPAD meter was a better screening measure of photosynthetic capacity for measuring chlorophyll density in leaves than chlorophyll fluorescence. In the present study the different plant growth regulators were beneficial in enhancing the chlorophyll content of the treated plants and subsequent increase in the
SPAD value; the SPAD values increased with the application of higher concentration of plant growth regulators both Ethrel and auxins as shown in Table 3.

Photosynthetic efficiency as $\mathrm{Fv} / \mathrm{Fm}$ ratio was determined using a PEA meter. Initially leaf clips were attached to the mid position of each leaf and then the leaves were dark adapted for $10 \mathrm{~min}$. Then the fluorescence was measured using red light (1.5 sec, $\left.3000 \mu \mathrm{mol} \mathrm{m}^{-2} \mathrm{~s}^{-1}\right)$. Statistical comparison between different treatments showed that ethrel and auxins (IAA and NAA) application significantly increased the photosynthetic efficiency of treated Jatropha plants as shown in Table 3.

Nitrate reductase activity was analysed after application of ethrel and auxins. The results presented in the Table 3 showed that with the increase in the concentration of the ethrel and auxin, the nitrate reductase activity was positively affected and recorded an increase compared to control plants. The nitrate reductase activity of control plants was $2.105 \pm 0.024$ $\mu$ mol NO2- $\mathrm{g}^{-1}$ fresh wt.h ${ }^{-1}$, IAA $150 \mathrm{ppm}$ and NAA $150 \mathrm{ppm}$ 


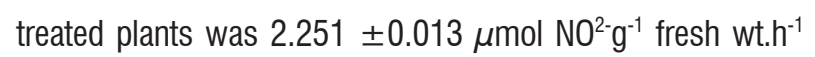
and 2.231 \pm 0.016 . With ethrel $150 \mathrm{ppm}$ treated plants NR

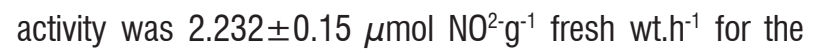
year 2009.

Proline acts as an osmoregulant under stress conditions. It plays diverse roles such as stabilization of proteins, membranes and subcellular structures, and protecting cellular functions by scavenging reactive oxygen species. Determination of proline content in treated and untreated plants (Table 3) showed that Proline content increased with the application of plant growth regulators. Significant increase was observed during vegetative and reproductive stage followed by a decrease during maturity stage. Highest proline content was observed in ethrel $150 \mathrm{ppm}$ treated plants which was $5.302 \pm 0.62(\mu \mathrm{g} / \mathrm{g}$ fresh wt) in the year 2008 and $5.300 \pm 0.25(\mu \mathrm{g} / \mathrm{g}$ fresh $\mathrm{wt})$ in the year 2009 compared to control which recorded $5.244 \pm 0.25(\mu \mathrm{g} / \mathrm{g}$ fresh wt) in 2008 and $5.225 \pm 0.31(\mu \mathrm{g} / \mathrm{g}$ fresh $\mathrm{wt})$ in the year 2009

Table 3. Effect of plant growth regulators on biochemical patterns of J. curcas L.

\begin{tabular}{|c|c|c|c|c|c|c|c|c|c|c|}
\hline \multirow[t]{2}{*}{ Treatment } & \multicolumn{2}{|c|}{$\begin{array}{l}\text { Total Chlorophyll content } \\
\text { (mg/g) }\end{array}$} & \multicolumn{2}{|c|}{ SPAD value } & \multicolumn{2}{|c|}{ PEA (Fv/Fm ratio) } & \multicolumn{2}{|c|}{$\begin{array}{c}\text { Nitrate reductase activity } \\
(\mu \mathrm{mol} \text { N02-g-1 fresh } \\
\text { wt.h-1) }\end{array}$} & \multicolumn{2}{|c|}{$\begin{array}{l}\text { Proline content } \\
(\mu \mathrm{g} / \mathrm{g} \text { fresh wt) }\end{array}$} \\
\hline & 2008 & 2009 & 2008 & 2009 & 2008 & 2009 & 2008 & 2009 & 2008 & 2009 \\
\hline Control & $1.81 \pm 0.07$ & $1.81 \pm 0.10$ & $24.02 \pm 1.25$ & $24.07 \pm 2.03$ & $0.69 \pm 0.04$ & $0.69 \pm 0.02$ & $2.10 \pm 0.01$ & $2.11 \pm 0.02$ & $5.24 \pm 0.25$ & $5.23 \pm 0.31$ \\
\hline Ethrel $_{50 \mathrm{ppm}}$ & $1.82 \pm 0.06$ & $1.82 \pm 0.06$ & $24.46 \pm 1.56$ & $24.82 \pm 1.56$ & $0.69 \pm 0.06$ & $0.69 \pm 0.02$ & $2.19 \pm 0.02$ & $2.13 \pm 0.02$ & $5.27 \pm 0.45$ & $5.28 \pm 0.25$ \\
\hline Ethrel $_{100 \mathrm{ppm}}$ & $1.83 \pm 0.04$ & $1.83 \pm 0.07$ & $24.49 \pm 1.56$ & $25.33 \pm 1.34$ & $0.69 \pm 0.05$ & $0.70 \pm 0.05$ & $2.20 \pm 0.02$ & $2.19 \pm 0.02$ & $5.28 \pm 0.48$ & $5.30 \pm 0.31$ \\
\hline Ethrel $_{150 \mathrm{ppm}}$ & $1.82 \pm 0.05$ & $1.83 \pm 0.03$ & $25.17 \pm 2.32$ & $25.72 \pm 1.78$ & $0.69 \pm 0.06$ & $0.70 \pm 0.07$ & $2.21 \pm 0.03$ & $2.23 \pm 0.2$ & $5.30 \pm 0.62$ & $5.30 \pm 0.25$ \\
\hline $\mathrm{IAA}_{50 \mathrm{ppm}}$ & $1.82 \pm 0.01$ & $1.82 \pm 0.01$ & $24.62 \pm 1.23$ & $24.76 \pm 2.56$ & $0.68 \pm 0.05$ & $0.69 \pm 0.06$ & $2.19 \pm 0.01$ & $2.19 \pm 0.01$ & $5.26 \pm 0.29$ & $5.28 \pm 0.12$ \\
\hline $\mathrm{IAA}_{100 \mathrm{ppm}}$ & $1.82 \pm 0.08$ & $1.82 \pm 0.05$ & $25.43 \pm 2.21$ & $25.22 \pm 3.45$ & $0.69 \pm 0.06$ & 0.7 & $2.20 \pm 0.02$ & $2.20 \pm 0.01$ & $5.27 \pm 0.37$ & $5.29 \pm 0.31$ \\
\hline $\mid \mathrm{IAA}_{150 \mathrm{ppm}}$ & $1.83 \pm 0.11$ & $1.83 \pm 0.09$ & $25.82 \pm 1.23$ & $26.34 \pm 1.56$ & $0.70 \pm 0.05$ & 0.71 & $2.21 \pm 0.02$ & $2.25 \pm 0.01$ & $5.29 \pm 0.45$ & $5.30 \pm 0.22$ \\
\hline $\mathrm{NAA}_{50 \mathrm{ppm}}$ & $1.81 \pm 0.03$ & $1.82 \pm 0.04$ & $24.44 \pm 1.27$ & $24.63 \pm 2.56$ & $0.68 \pm 0.07$ & 0.69 & $2.19 \pm 0.02$ & $2.14 \pm 0.01$ & $5.26 \pm 0.42$ & $5.25 \pm 0.28$ \\
\hline NAA ${ }_{100 p p m}$ & $1.82 \pm 0.07$ & $1.82 \pm 0.06$ & $25.32 \pm 2.13$ & $25.29 \pm 2.45$ & $0.69 \pm 0.06$ & 0.70 & $2.2 \pm 0.01$ & $2.14 \pm 0.02$ & $5.28 \pm 0.56$ & $5.28 \pm 0.26$ \\
\hline $\mathrm{NAA}_{150 \mathrm{ppm}}$ & $1.83 \pm 0.08$ & $1.82 \pm 0.04$ & $25.79 \pm 3.25$ & $26.70 \pm 3.25$ & $0.70 \pm 0.05$ & 0.71 & $2.21 \pm 0.02$ & $2.23 \pm 0.02$ & $5.29 \pm 0.26$ & $5.29 \pm 0.21$ \\
\hline S.Em. & 0.005 & 0.004 & 0.264 & 0.262 & 0.004 & 0.003 & 0.031 & 0.025 & 0.013 & 0.02 \\
\hline CD at $5 \%$ & 0.014 & 0.011 & 0.745 & 0.739 & 0.011 & 0.009 & 0.089 & 0.07 & 0.037 & 0.058 \\
\hline
\end{tabular}

\section{DISCUSSION}

Through the present investigation it was found that the plant growth regulators ethrel, IAA and NAA caused variable beneficial effects on different morpho-physiological and biochemical parameters of Jatropha plants. Results regarding morphological parameters presented in the Table 1 showed that ethrel at all concentrations and prominently at the higher doses i.e. 100 and 150 ppm restricted the plants growth. Koch and Moore (1990) suggested that ethylene inhibited stem elongation in whole green plants either by inhibiting basipetal IAA translocation or by affecting IAA metabolism in some manner or some other, auxin-independent action. Reduction in the height of plants during early season helped the plants to make better use of the available water; thus helping in better performance of the plants in field conditions. Auxins both IAA and NAA treated plants had increased height compared to the control plants. The $150 \mathrm{ppm}$ concentrations of IAA and NAA had a more prominent effect. Increased height by IAA applications might be due to interaction between different plant hormones such as kinetin, IAA, ethylene, and gibberellin, in-vivo. Also auxin binding protein (ABP1) mediated auxin signaling might had switched on the genes involved in cell expansion such as 'expansin' and 'extension' and also through membrane hyper polarization (Teale et al., 2006). The collar diameter was found to be increased by the application of plant growth regulators both Ethrel and auxins compared to control. This increase may be due to interaction between Ethrel derived ethylene and endogenous auxin which might had promoted xylem 
production and cambial growth and also due to induction of enzymes involved in lignifications by Ethrel derived ethylene. Normanly (1997) proposed that the concentration of the hormone, the ratio of IAA to other plant hormones, and the sensitivity of tissues to IAA may all be primary determinants of auxin action. Love et al. (2009) demonstrated that Ethylene was an endogenous regulator of meristem growth in Populus. Both applied and ectopically produced ethylene stimulated xylem growth by means of cambial cell division. Ethrel spray on Jatropha curcas plants caused a reduction in the tree spread and tree volume as reflected by the data of our study (Table 1). The effect was significant for higher concentration rates i.e. 100 and $150 \mathrm{ppm}$ when compared to control plants for both the years. Tree spread and volume are collaborative effect of growth in all the direction of the plant and thus may represent the overall growth of the plant in all the directions. Ethrel application restricted vegetative growth of plants during early growing season. The decrease in plant height was compensated by increase in radial growth. Pakasorn et al. (1995) reported that growth regulator 2-chlorethylphosphonic acid induced anatomical and biochemical changes of cambium and enhanced stability of bark. Cell division became more intensive in the radial direction; accordingly the shoots growth slowed down. Results indicated that auxins- both IAA and NAA increased the growth parameters of the plants resulting in increased overall development as compared to control plants. Higher concentrations, 100 and $150 \mathrm{ppm}$ achieved significant increase in tree spread and tree volume over control plants. Leblanc et al. (1999) and Steffens et al. (2001) auxin binding receptor protein (ABP1) played an important role in auxin perception and function. Jones et al. (1998) working on transgenic tobacco plant suggested that the increased cell size caused by the over-expression of ABP1 was compensated by a reduced frequency of cell divisions. The increase in the tree spread and volume of Jatropha plants by application of auxins, IAA and NAA might be due to enhanced cell division and cell enlargement of the plant cells thus, causing an overall growth of the plants.

All plant growth regulators showed significant effect in lowering the vegetative period of the Jatropha plants and marked the onset of reproductive phase when compared to control. The results presented in the Table $2 \mathrm{a}$ and Figure 1, 2 and 3 indicated that the plant growth regulators increased the number of inflorescence per plant and number of both male and female flowers compared to control and significant effect was observed at higher concentration of plant growth regulators by both Ethrel and auxin spray. Ethrel spray on Jatropha curcas plants released ethylene; increase in the ethylene concentration at the meristem might have induced the development of floral organs. This was in agreement with the study of Trusov and Botella (2006) in pineapple. They suggested that small burst of ethylene production in the meristem in response to environmental cues initiated flowering in pineapple. It was found that Annanas comosus ACC synthase gene AcACS2 was induced in the meristem during induction of flowering in pineapple. The results represented in Table 2a and Figure 1, 2 and 3 also suggested that foliar spray of auxin, both IAA and NAA shortened the vegetative period of Jatropha plants and induced earlier reproductive growth in them in comparison to control. It is suggested that spraying growth regulator at flower bud initiation stage might have suppressed the male bud initiation and enhanced female flower bud initiation in the present study. Our results are in concert with those reported by Hilli et al. (2008) on ridge guard. NAA spray at the concentration of $50 \mathrm{ppm}$ decreased the number of days for first female flower appearance during summer and kharif season, respectively. Also it resulted in more number of female flowers during summer and kharif season. The increase in the number of inflorescence, male and female flowers per plants in treated plants compared to control plants may be due to the synergistic effect of ethylene and auxin and their effect on concentration of other hormones such as gibberellins and cytokinin within the cell. Ethylene might have increased the growth rate leading to a large apical meristem and greater number of inflorescence (Hans et al. 1990). It was also observed that the plant growth regulators decreased the male- female ratio of the plants and thus favoured feminization of Jatropha plants (Table 2a and Figure 2 and 3 ). Induction of female flowers by the application of plant growth regulators has been reported in other plants of cucumber, squash, zucchini and melon (Owens et al., 1980; Mancini and Calabrese, 1999; Ekaterina et al., 2005). Induction of femaleness by ethylene in Jatropha plants may be related to regulatory effects of ethylene on expression of specific floral organ identity genes, although this remains to be determined. The increase in femaleness after Ethrel applications may be also related to effect of ethylene on auxin and gibberellins (GA) concentrations in vivo and their interaction (Yamasaki et al., 2000; Trusov and Botella 2006). 
The results (Table 2b and Figure 4 and 5) indicated that the plants treated with growth regulators had a significant increase in the fruit and seed yield per plant compared to untreated plants in both the years of study. This increase due to use of ethrel application may be attributed to the balanced water use during vegetative phase, reduction of stress condition during reproductive phase and increase in the number of fertile female flowers Shekoofa and Yahya (2008). Whereas in auxin treated plants this increase in yield might be due to the switching of the floral primordial towards development of female flowers, fertilization of more female flowers, increase in the number to better networking between source and sink relationship (Chaudhary et al., 2006).

Biochemical parameters such as chlorophyll content, photosynthetic rate, nitrate reductase activity, crude protein content and proline content of the treated Jatropha plants were significantly increased after the application of plant growth regulators as shown in Table 3. Prominent effect was observed during vegetative and reproductive stage. It was observed that the application of plant growth regulators increased the chlorophyll content of the plants. The synergistic effect of ethrel and auxin on chlorophyll content of Jatropha curcas plants might be due to broadening of exterior mesophyll cells which might have provided more space for chloroplast arrangement (Grbic and Bleecker 1995; Luo et al., 1996, 1997). Czerpak and Bajguz (1997, 2002) working on chlorella and Wolffia observed similar results after application of IAA. With the age of the plants the tissues might have become sensitive to the in vivo ethylene content and senescence was accelerated. Richardson et al. (2002) stated that soil plant analysis development (SPAD) chlorophyll meter reading (SCMR) is an indicator of the photosynthetically active light-transmittance characteristics of the leaf, which is dependent on the unit amount of chlorophyll per unit leaf area (chlorophyll density). Spray of plant growth regulators on Jatropha curcas plants was found beneficial in maintaining the nitrogen status and chlorophyll content of the plants reflected by the higher SPAD values of the plants. Similar results were reported by Munns et al. (2006) in wheat and other cereals. The chlorophyll fluorescence ratio Fv/Fm was correlated with the efficiency of leaf photosynthesis (Bjorkman and Demming 1987). When plants were subjected to a wide range of environmental stresses there was a decline in its fluorescence ratio indicating photo inhibitory damage caused by incident photosynthetic photon flux density (PPFD). The results presented in the Table 3 indicated increase in the chlorophyll fluorescence rate after Ethrel and auxin spray. This may be due to increase in the amount of chlorophyll and due to enhancement of stomatal conductance and increase in the carboxylation activity of mesophyll cells by the application of plant growth regulators. Similar results were presented by Khan (2005) in Brassica juncea and Chaturvedi et al. (2009) in Saussurea costus by application of Ethephon. Czerpak et al. (2004) also reported increase in the net photosynthetic rate to $124.5 \%$ by NAA, $127.2 \%$ by IAA and $144.2 \%$ by PAA in Wolfia arrhiza. With the increase in the age of the plants the chlorophyll content decreased leading to a decreased chlorophyll fluorescence rate at maturity. Lea (1997) suggested that nitrate reductase activity as the main limiting step in the nitrate assimilation and amino acid production. The results presented in the Table 3 indicated that nitrate reductase activity was significantly affected by plant growth regulators. The Ethrel treatment increased the nitrate reductase activity of Jatropha plants significantly over control. The results of the present investigation are in agreement with those presented by Solomon and others (1988); Pujade-Renaud et al. (1994) working on sugarcane and rubber plant. The increase in the nitrate reductase activity by Ethrel spray in the present study may be due to the modulations in the membrane permeability and activation of several enzyme activities such as glycolysis acceleration and increased adenylic pool, polysomes and rRNA contents by ethephon spray (Tupy, 1973; Lieberman, 1979). The auxins (IAA and NAA) were both beneficial in increasing the nitrate reductase activity. Similar studies have been reported by Ali et al. (2007) working on chick pea and groundnut.

According to Vanrensburg et al. (1993); Bohnert and Shen (1999) proline seemed to have diverse roles under osmotic stress conditions, such as stabilization of proteins, membranes and subcellular structures, and protecting cellular functions by scavenging reactive oxygen species. The results presented in the table 3 revealed that the application of plant growth regulators enhanced the proline content of the treated Jatropha curcas plants compared to the untreated plants. The results suggested that Ethrel and auxins application increased the proline content of the plants and prominent effect was observed with higher concentration i.e. 100 and $150 \mathrm{ppm}$ during both the years of investigation. According to Bleecker and Schaller (1996) 
ethylene perception involved a family of receptors that trigger a signal transduction cascade. Manipulations at gene level of the treated plants might have led to an upregulation of proline synthesis and its content. During stress, Napal et al. (2000) reported that auxin signaling was mediated by AXR1 gene which belonged to AUX/ IAA gene family. Ulmasov et al. (1994) reported that stress signals induced auxin response gene family GH2/4 like genes. Accumulation of proline in auxin treated plants might be due to proline de novo synthesis or decreased degradation or both.

In conclusion, the application of plant growth regulators was beneficial for overall development of the plant and increasing the yield of the Jatropha curcas plants. It is suggested that higher concentration of Ethrel and IAA (i.e. $150 \mathrm{ppm}$ ) was found to promote morpho-physiological development, increase female flower development leading to feminization, decrease in male-female ratio, resulting in an improved yield of the plants expressed as an increase in both fruit and seed yield. Biochemical parameters such as chlorophyll content, SPAD and PEA readings, nitrate reductase activity and proline content are found to be beneficially affected by the application of Ethrel, IAA and NAA spray and prominently at higher doses.

\section{REFERENCES}

Becker K, Makkar HPS (2008) Jatropha curcas: a potential source for tomorrow's oil and biodiesel. Lipid Technol 20: 104-107.

Burg SP (1962) The physiology of ethylene formation. Ann. Rev. Plant Physiol 13: $235-302$.

Burg SP, Burg EA (1966) The interaction between auxin and ethylene and its role in plant growth. Proc Nat Acad Sci (Wash) 55: 262-269.

Chaudhry NY (1997) Effect of indole 3 acetic acid and gibberellic acid on petioles and leaves of Abelmosehus esculentus (Linn.) Acta Sci 7: 103-130.
Dehgan B, Webster GL (1979) Morphology and infrageneric relationship of the genus Jatropha (Euphorbiaceae). University of California Publications in Botany, Vol. 74.

Dole JM, Wilkins HF (1999) Plant growth regulation. In: Floriculture: Principles and Species (Eds J.M. Dole, H.F. Wilkins). Prentice-Hall Press, Englewood Cliffs, NJ, USA.

Ekaterina P, Holly A, Little S, Hammar A, Grumet R (2005) Effect of modified endogenous ethylene production on sex expression, bisexual flower development and fruit production in melon (Cucumis melo L.) Sex Plant Reprod 18: 131-142.

Eklund L, Little CHA (1995) Interaction between indole-3-acetic acid and ethylene in the control of tracheid production in detached shoots of Abies balsamea. Tree Physiol 15:27-34.

Foidl N, Kashyap A (1999) Exploring the Potential of Jatropha curcas in Rural Development and Environmental Protection. Rockefeller Foundation, New York.

Francis G, Edinger R, Becker K (2005) A concept for simultaneous wasteland reclamation, fuel production, and socio-economic development in degraded areas in India: need, potential and perspectives of Jatropha plantations. Natural Resource Forum 29:12-24.

Gahukar RT (2009) Food security: The challenges of climate change and bioenergy. Curr Sci 96: 26-28.

Heller J (1996) Psycic nut, Jatropha curcas. Promoting the conservation and uses of underutilized and neglected crop1. IPGRI, Rome, Italy. pp 66.

Hilli JS, Vyakaranahal BS, Biradar DP (2008) Influence of growth regulators and stages of spray on seed quality of ridge gourd (Luffa acutangula L. Roxb). Karnataka Journ Agri Sci 21: 198-201

Jones N, Miller JH (1991) Jatropha curcas — a multipurpose species for problematic sites. Land Res Series 1:1-12.

Jongschaap REE, Corre WJ, Bindraban PS, Bradenburg WA (2007) Claims and facts on Jatropha curcus L. Global Jatropha curcus evaluation, breeding and propagation programme.Plant research international B.V. Wageningen Stichting Het Groene Woudt laren. Report 158.

Katwal RPS, Soni PL (2003) Biofuels: an opportunity for socioeconomic development and cleaner environment. Indian Forester 129: 939-949.

Little CHA, Savidge RA (1987) The role of plant growth regulators in forest tree cambial growth. Plant Growth Regul 6:137-169.

Savidge RA (1988) Auxin and ethylene regulation of diameter growth in trees. Tree Physiol. 4:401-414.

Schmook B, Serralta- Peraza L (1997) Jatropha curcas: distribution and uses in the Yucatan Peninsula of Mexico. In: G.M. Gübitz, M. Mittelbach and M. Trabis (Eds.). Biofuels and industrial products from Jatropha curcas. DbvVerlag für die Technische Universitat Graz, Graz, Austria, pp. 53- 57. 